\title{
RESPONSE OF A HAWK OWL TO A LURE
}

\author{
by B. M. FISHER*
}

The Hawk Owl is a scarce resident in Alberta. It was formerly common but its numbers have been considerably reduced in recent years. ${ }^{4}$

On October 30, 1973, four students on an ecology field trip found a Hawk Owl in a black spruce-muskeg community, 2 miles N-NE of Looma, Alberta. (Lat. $53^{\circ} 23^{\circ} \mathrm{N}$, Long. $113^{\circ}$ $\left.15^{\prime} \mathrm{W}\right)$. We observed the owl between 3:00-4:30 p.m. on an overcast day with gusting winds, $20-30 \mathrm{mph}$. The temperature was about $4{ }^{\circ} \mathrm{C}$.

To lure the owl, a white string was tied around the neck of a dead Meadow Vole (Microtus pennsylvanicus) which was thrown in the vicinity of the perched owl, then pulled across the ground erratically. A similar technique for studying hunting behaviour of Great Gray Owls proved successful using a study skin of a Meadow Vole. ${ }^{2}$

The owl first swooped down to within 5 feet of the ground and then straight up to a perch in a black spruce (Picea mariana). Dr. D. L. Pattie approached to within 50 yards of the owl and failed on three initial attempts to lure it. The owl was constantly turning in all directions and on a few occasions spotted the vole but instead of attacking, swooped down to within 8 feet of the ground and straight up to the perch in a black spruce directly above Dr. Pattie. It then had a better view of the moving vole but seemed reluctant to attack. From 50 yards away, I managed to attract the owl's attention

*8030 - 132nd Ave.

Edmonton, Alberta.

T5C 2B4 to the vole by alternating quic movements with short pauses. The ow immediately flew within 20 yards me. Within 10 seconds it swoope down without a flap of its wings and with both legs extended, landed on th back half of the vole. The owl, 8 feet $\mathrm{i}$ front of me, was holding its wings ou as if balancing itself. I pulled on th string; at this movement the owl struc the vole's head with two sharp thrus of its beak. Then it picked up the vol with its beak and flew into the fores However, the string became entangle in bushes and after several unsuc cessful attempts to fly off with it "prey" the owl flew away. W retrieved the vole and threw it into th trees, 15 feet in front of us. The strin dropped over a spruce bough so th: the vole was dangling in mid-air. Upo jerking the string, the owl swoope down to a branch a foot away an jumped onto the vole. After 3 seconds, it released the vole and fles 10 yards to a dead tree stump 12 fee off the ground. Again the vole wa retrieved and thrown into the trees 1 yards in front of us. The owl swoope down without flapping its wings an landed a foot from the vole which wa resting on a branch beneath a dens spruce bough. The owl walked abou on the bough, tipping its head $90^{\circ} \mathrm{t}$ each side and looking at the vole; then reached through the dense spruc bough and picked the vole up in it claws. After 30 seconds, the ow released it and flew to its perch.

Next we untied the vole and threw into the woods about 20 yards fror the owl. It at once swooped down in it characteristic dive, seized the vole i 
its claws, picked it up in its beak, flew to its perch, and began to pick and pull at the vole's head, holding the body on the stump with one foot. For the first 3 minutes the owl constantly surveyed its surroundings and picked at the vole with a meagre effort. After a Blackbilled Magpie landed nearby, the Hawk Owl made no attempt to eat its prey but watched the magpie closely. The moment the magpie flew away the owl began tearing the head off the vole, devouring it whole. The remainder of the vole was devoured in smaller pieces - fur, flesh and viscera.

The tameness and curiosity of the Hawk Owl was evident, as mentioned by E. T. Seton in $1890 .^{1}$ It appeared to locate the vole mostly by sight as it was upwind prior to all attacks. The owl was interested in the vole mainly when it was moving. This same observation has been made on Great Gray Owls."

The Hawk Owl we observed was south of its boreal breeding range in which it usually winters. However, on rare occasions shortages in food forces these birds south. ${ }^{1}$ This individual was likely hungry, explaining its strong response to the lure. Smith had a nesting Hawk Owl take a dead "field mouse" off a stick.

I am grateful to Dr. D. L. Pattie and Darrell J. Robinson for their assistance in preparing this note.

'BENT, A. C. 1961. Life history of North American birds of prey. Purt two. Dover Publications Inc., N.Y., N.Y. 482 pp.

'BRUNTON, D. F. and R. PITTAWAY, Jr. 1971. Observations of the Great Gray Owl on winter range. Can. Field-Nat. 85: 315-322.

GODFREY, W. E. 1966. The birds of Canada Nat. Mus. of Canada. Bull. No. 203, Ottawa, $428 \mathrm{pp}$

SALT, W. R. 1972. The birds of Alberta. Queen's Printer, Gov't. of Alberta. Edmonton, Alberta. $511 \mathrm{pp}$.

'SMITH, N. F. 1922. The Arnerican Hawk Owl. Can. Field-Nat. 36: 68-71.

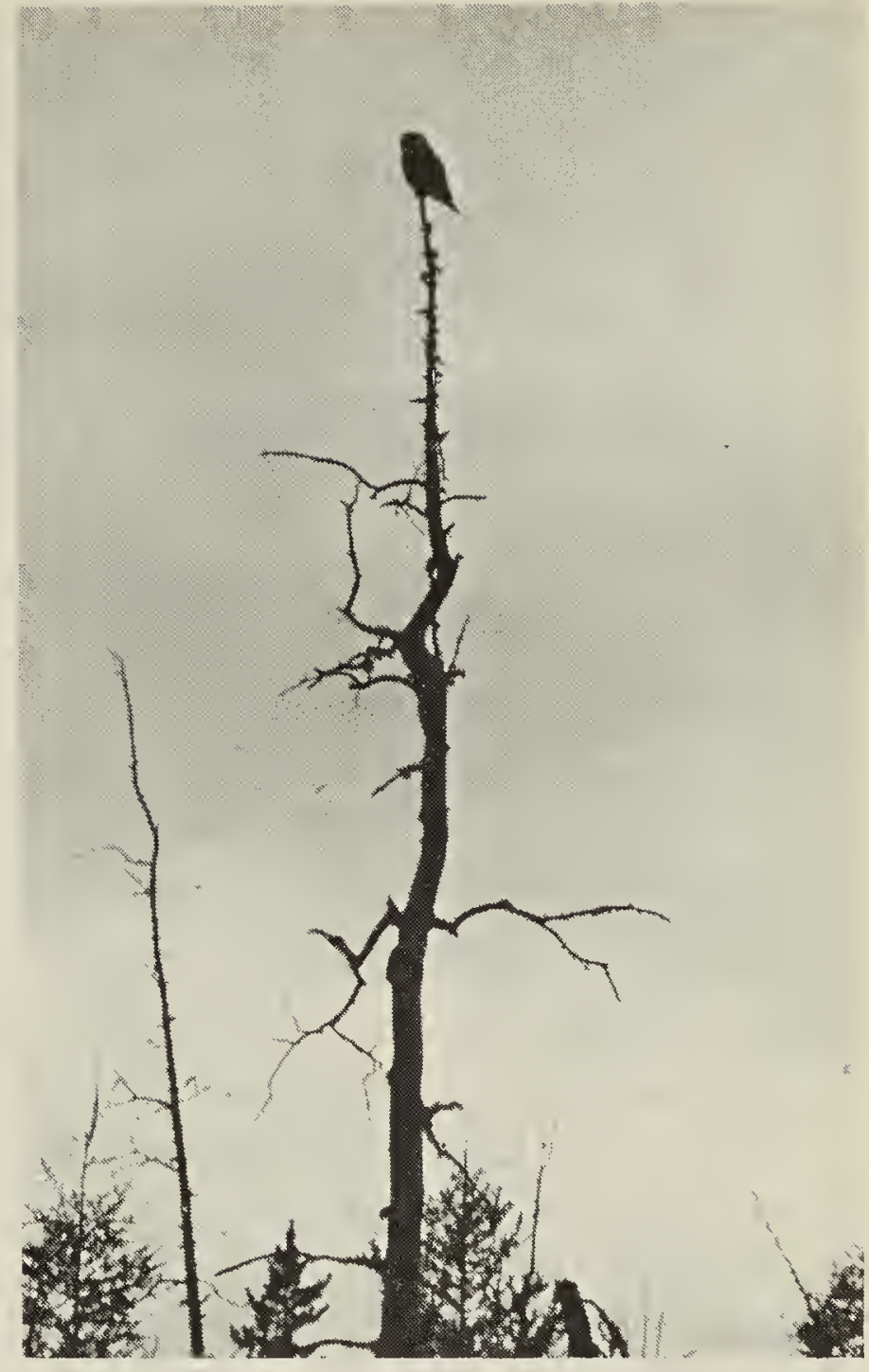

Hawk Owl

Fred W. Lahrman

Hawk Owl

Robert J. Long

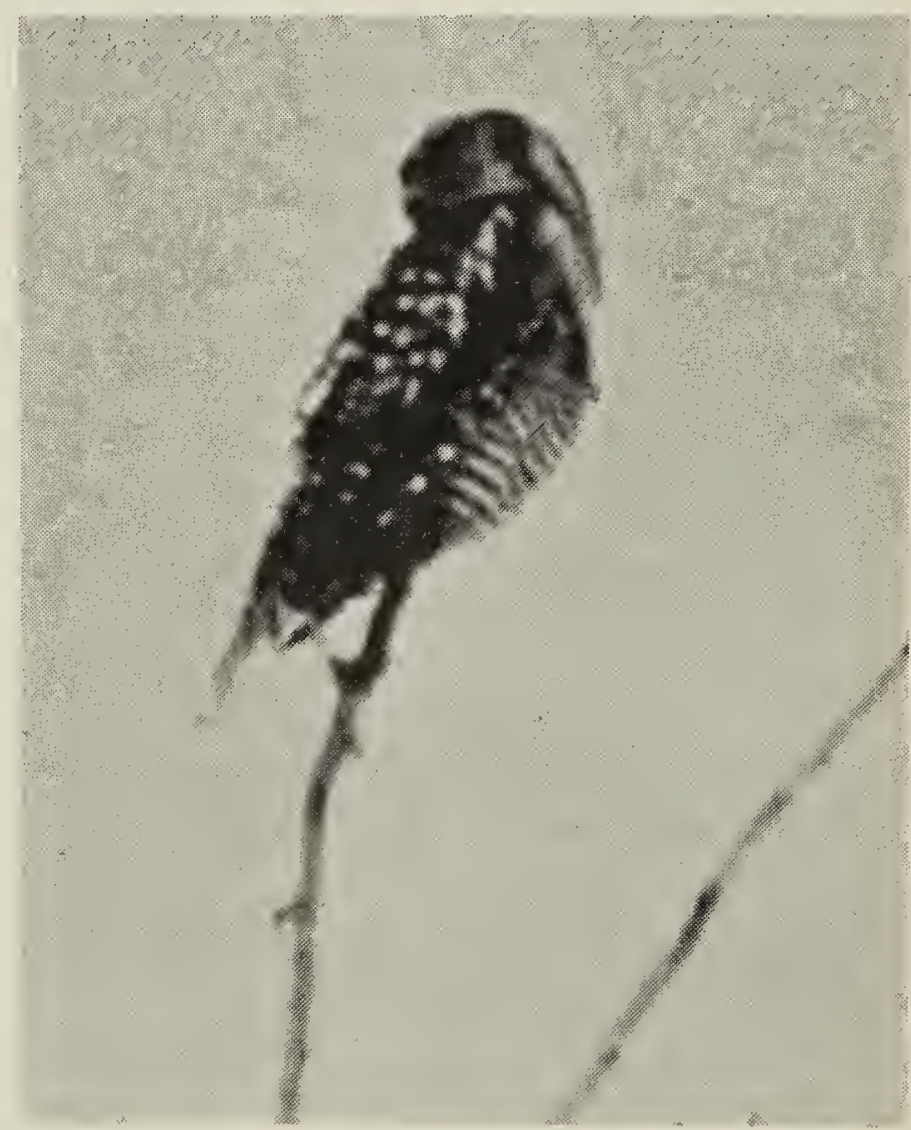

